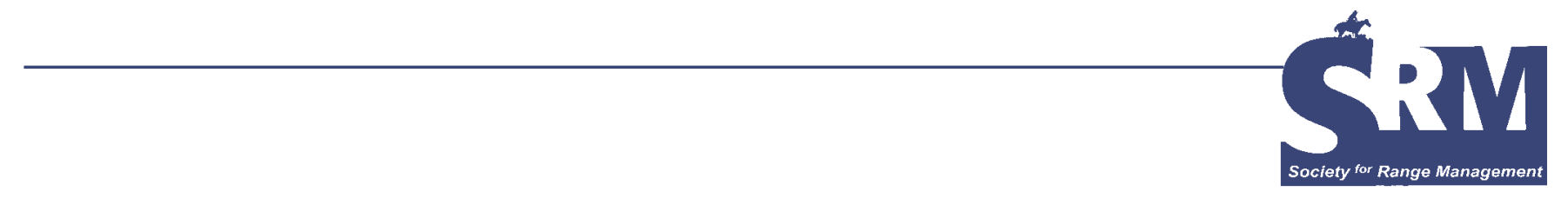

\title{
Climate Change Impacts on Northwestern and Intermountain United States Rangelands
}

\section{By Jeanne C. Chambers and Mike Pellant}

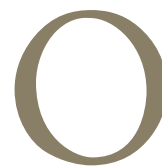

ur focus is on the Pacific Northwest and Intermountain Region including the Great Basin, Columbia Plateau, Colorado Plateau, and surrounding areas. The climate of this large, arid to semiarid region is defined by generally low and highly variable precipitation. Much of the yearly precipitation arrives as winter snow because most of the moisture comes as frontal storms in winter instead of convective storms in summer. Strong gradients in both temperature and precipitation exist with mountainous areas receiving as much as $127 \mathrm{~cm}$ (50 inches) of precipitation a year, and lower elevation cold deserts receiving only about 13 to $18 \mathrm{~cm}$ (5 to 7 inches). The distribution of both species and vegetation communities is determined by these gradients. At low to mid-elevations, cold desert vegetation dominates including salt desert shrub, sagebrush steppe and sagebrush semiarid desert, and pinyon and juniper woodlands. At the periphery of the cold deserts and on mountain ranges, diverse forest types occur, including pines, firs, and spruce. Riparian areas, aspen ecosystems, and inter-basin forests dominated by drought-tolerant pines comprise smaller land areas, but support much of the region's biodiversity.

Much of the land area is managed by the federal government with the Bureau of Land Management responsible for managing lower elevation shrublands and woodlands and the Forest Service responsible for higher elevation and mountainous areas. Consequently, the region's rangelands are managed for multiple uses, including nonextractive uses such as terrestrial and aquatic habitat for wildlife and fisheries, production of a high quality water supply, and recreational opportunities, and extractive uses such as mineral, energy, timber, and livestock production. Private, state, other federal agencies, and tribal governments manage rangelands for similar uses.

\section{Projected Climate Change for the Region}

Increased Temperature and Changes in Precipitation The change in temperature and precipitation in the region due to climate change will depend on the rate and magnitude of the increase in $\mathrm{CO}_{2}$ and other heat-trapping emissions, and will vary across the region due to storm patterns and large differences in topography. In the last $100 \mathrm{yr}$, the region warmed by 0.5 to $1.5^{\circ} \mathrm{C}\left(1\right.$ to $\left.3^{\circ} \mathrm{F}\right)$ and is projected to warm another 3.6 to $9^{\circ} \mathrm{F}\left(2\right.$ to $5^{\circ} \mathrm{C}$ ) by the end of the century. Annual precipitation increased by $10 \%$ on average, and by as much as $30-40 \%$ in some areas. Projected changes in precipitation in the West are inconsistent as to sign with average changes near zero. California and the central to southern Great Basin might receive more precipitation, and any increases in precipitation are likely to occur largely in winter with little change or decreases in summer. Climatic variability and, consequently, frequency of both droughts and floods are predicted to increase.

The effectiveness of future precipitation will depend on the degree of warming and the effects on snowpack and evapotranspiration. Snowpacks have declined across the western United States since about 1950, especially in areas of the interior west with milder climates, and these losses are likely to increase. Evapotranspiration is predicted to increase whether or not precipitation increases. Thus, even those projections that indicate increases in precipitation show water availability decreasing and will make water management (surface, ground, and soil) a critical component of management response.

\section{Overview of Climate Change Impacts Changes in Water Resources}

Water is the region's most critical resource. Spring snowmelt supplies the necessary water resources to maintain 
stream and river channels and their associated riparian and aquatic ecosystems. Storage of spring runoff in reservoirs provides much of the region's water supply for ranching operations, agriculture, urban areas, and industry. As a result of warming, more winter precipitation is falling as rain, and the variation in spring stream flows has increased. Snowmeltdriven streamflow in spring is already about 10-15 d earlier than $50 \mathrm{yr}$ ago. This earlier snowmelt could be significantly increased by greater deposition of dust on the snowpacks of downwind mountains, resulting in higher absorption of solar radiation. A continuation of existing trends will result in increases in winter flows and winter flood risks, smaller warm season reserves and rates of runoff, and generally warmer water temperatures. Areas with increasing dryness will exhibit decreases in groundwater recharge.

Changes in flow regimes and reductions in stream and spring discharge, coupled with increased water temperatures in summer, will decrease water quantity and quality for aquatic and wildlife species, and livestock, wild horses, and burros. The predicted changes in river and stream flows and increases in water temperatures are likely to be harmful to several native fish species, including most species of Northwest salmon. Reservoirs, pipelines, and troughs installed by land management agencies and livestock permittees could have reduced capacity to supply needed water increasing competition for both water and forage among livestock and wildlife.

Increasing demands on both surface and groundwater by the region's growing human population could increase conflicts over water use. For example, approval of new permits to a regional groundwater aquifer extending from Salt Lake City, Utah to Death Valley, California to supply water to Las Vegas and adjacent communities could trigger declines in water tables, spring discharge, wetland area, and streamflow, and negatively affect threatened, sensitive, and endangered species, and thousands of rural domestic and agricultural water users.

\section{Changes in Species and Ecosystems}

Increases in temperatures and changes in precipitation likely will result in shifts in species distributions and reorganization of rangeland communities. In this topographically diverse region, some species have the potential to migrate upslope with increases in temperature as was observed in the early to mid-Holocene $(10,500$ to $5,000 \mathrm{yr}$ ago). Alpine ecosystems at the tops of some mountain ranges might disappear, and a general reduction in suitable habitat could occur for species adapted to northern climates. As the number of frost-free days progressively increases, some species will have the potential to migrate to the north. With each $1^{\circ} \mathrm{C}$ increase in temperature, a $12 \%$ loss of current sagebrush habitat is predicted. The southern limit for many sagebrush species might shift to the northern Great Basin, whereas the northern limit of warm-desert species at the Mojave-Great Basin ecotone, such as creosote bush (Larrea tridentata), could move to the central Great Basin.

Increases in winter precipitation in southern parts of the region could increase plant growth, cover, and annual productivity. General increases in precipitation could result in expansion of woody species and shifts from shrublands and grasslands to woodlands and forests. However, the decreases in effective precipitation predicted for much of the region could cause declines in vegetation productivity and shifts from forests, woodlands, and shrublands to grasslands and deserts. Other drivers, including elevated $\mathrm{CO}_{2}$, will interact with temperature and precipitation changes affecting plant distribution and production. Elevated $\mathrm{CO}_{2}$ has the potential to increase rangeland plant productivity through increases in water-use efficiency, provided there is sufficient water to promote growth. Native $\mathrm{C}_{3}$ (cool season) species are positively affected by higher $\mathrm{CO}_{2}$ but so are cheatgrass, red brome, and other invasive species.

\section{Loss of Biodiversity}

This diverse region is home to many endemic species. Climate change and rangeland degradation have placed numerous species at risk, including sage grouse and Northwest salmon. Approximately 20\% of the sagebrush ecosystem's native flora and fauna are considered imperiled, and many sagebrush-associated species are declining in numbers. Widespread loss of habitat associated with streams, springs, and riparian and wetland areas has occurred due to groundwater extraction, surface diversion of streams and rivers, and excessive use of riparian areas. Introduction of more than 50 nonnative fish and invertebrate species by the public or fishery management agencies, coupled with habitat loss, have caused multiple species extinctions of native fish and invertebrates since the late 1800s.

The projected rate of climate change, coupled with habitat fragmentation and barriers to migration due to increasing development, likely will impede many species from migrating to more suitable habitats in the north. An increase in local extinctions is likely for several mammalian, avian, and butterfly species. Some salmonid fish species are likely to be restricted to higher elevations or to have smaller geographic distributions. Where climate change and higher temperatures favor invasive species, certain natives are likely to be displaced. If fire severity and size increase, shifts in the distribution and abundance of dominant plant species could affect the habitat of some sensitive or threatened plant and animal species. An increase in infectious disease and insect outbreaks could place many species at risk.

\section{Increases in Exotic Species Invasions}

Rapid expansion of invasive species can be attributed to ongoing perturbations resulting from elevated $\mathrm{CO}_{2}$ and $\mathrm{N}-$ deposition, past and present land uses, and the direct and 
indirect effects of climate change. The most significant invasion in the region is the expansion and dominance of exotic annual grasses including medusahead (Taenatherum caput-medusa), red brome (Bromus madritensis subsp. rubens), and especially cheatgrass (Bromus tectorum) in mid- to low elevation woodlands and shrublands. Those sites with relatively low cover of perennial grasses and forbs are most susceptible to invasion. Fine fuels contributed by these annual grasses have resulted in a grass-fire cycle where fire return intervals have decreased from about $60-110 \mathrm{yr}$ to, in some cases, 3-5 yr. Repeated fires are resulting in conversion of woodlands and shrublands to homogenous landscapes dominated by exotic species. The current distribution of cheatgrass is limited by effects of cold temperatures on plant growth and reproduction. Under warming scenarios, the upper distributional limit of cheatgrass could greatly expand.

Numerous other noxious species are rapidly spreading through the region's shrublands and woodlands, including knapweeds (Centaurea spp.), yellow starthistle (Centaurea solstitialis), and rush skeleton weed (Chondrilla juncea). Exotic herbaceous perennials including perennial pepperweed (Lepidium latifolium) and exotic shrubs and trees such as saltcedar (Tamarix spp.) are invading wetland and riparian areas. Many of these invaders are capable of displacing native plant communities and altering watershed functions.

Conversion of native shrublands and woodlands to dominance by cheatgrass and other invasive species has the potential to alter carbon budgets and increase desertification (Fig. 1). Repeated fire resulting from dominance by annual grasses can result in conversion of shrublands and woodlands from carbon sinks to carbon sources. Large-scale change in land cover from diverse shrublands to homogenous grasslands potentially can influence the region's albedo affecting evapotranspiration and, ultimately, moisture transfer, convective activity, and rainfall. The net effect could be an increase in aridity of the region.

\section{Altered Fire Regimes}

Climate change is predicted to have multiple effects on fire regimes. In more arid areas, fire frequency and extent likely will be higher in years that promote growth of fine fuels (high fall, winter, and spring precipitation) or have fuel accumulation from the previous growing season. Increased temperatures will likely result in longer fire seasons with more fires occurring earlier and later than is currently typical and a potential increase in total area burned. An increase in extreme fire weather (hot and dry conditions) could result in both larger and more severe fires. In 2007, the era of the "mega fires" might have arrived when 653,000 acres burned in the Murphy Complex wildfire in Idaho and Nevada and 363,000 acres burned in the Milford Flat wildfire in Utah.

Current ecological conditions of the region's ecosystems will influence their responses to changes in fire regimes. In forests, a decrease in fire frequency due largely to fire
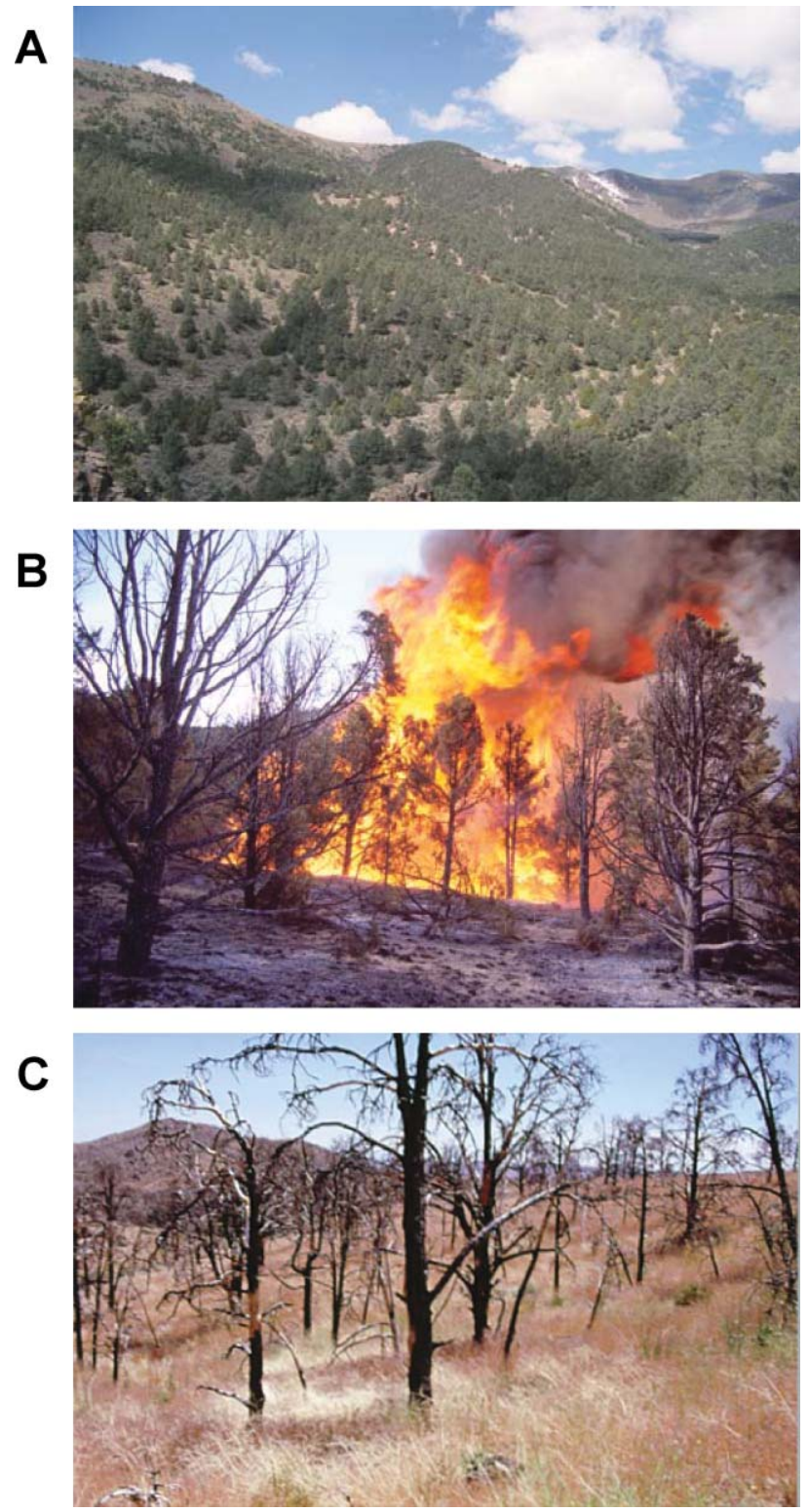

Figure 1. Expansion of pinyon and juniper trees into sagebrush ecosystems depletes understory vegetation and increases fuel loads (A) resulting in the potential for less frequent, higher severity fires (B) and invasion by annual grasses like cheatgrass $(\mathbf{C})$.

exclusion has resulted in shifts in species composition from early-seral, shade-intolerant species to late-seral shadetolerant species. Increases in vertical stand structure (fuel ladders) and biomass (fuel loads) already are resulting in more severe fires, and this trend is likely to continue. In pinyon-juniper woodlands decreased fire frequency due to overgrazing and fire exclusion coupled with favorable climatic condition for tree establishment early in the 20th century resulted in expansion of pinyon and juniper into mid-elevation sagebrush ecosystems. Now, as stands mature and fuel loads increase, risk of high-severity crown fires 
is increasing. In arid and semiarid shrublands and lowerelevation pinyon-juniper woodlands, progressive invasion of cheatgrass and other annual exotic grasses, which have greater flammability and fire spread than natives, is likely to continue to increase fire frequency and extent. Higher $\mathrm{CO}_{2}$ levels are likely increasing cheatgrass fuel loads due to increased productivity and higher lignin contents that might be reducing palatability and decomposition.

\section{Management and Policy Implications}

Climate change already has influenced current ecological conditions and successional trajectories, and the combination of past effects and projected changes likely will have even greater influences in the near future. Potential changes in species distributions and the reorganization of rangeland communities, coupled with uncertain productivity, will necessitate reevaluating current state and transition models and concepts related to potential natural communities. The ecological concepts of resistance to change and resilience, or the ability to recover from disturbance, are central to management models, but our current understanding is based on historical interpretations and future predictions are largely outside of our frame of reference.

Higher temperatures and increasing variability in precipitation will increase the difficulty of managing for sustainable rangelands, resulting in the potential for more litigation and political intervention. Natural population dynamics of many native and even introduced species are unlikely to respond quickly enough to changing climatic conditions to avoid widespread changes in plant communities. Livestock grazing is a major land use across much of the region and, without highly flexible livestock management options, land degradation could accelerate, especially during drought. Similarly, many large feral and native grazers could increase the rate of degradation without proactive management.

Human population growth, water resources, invasive species, fuels and fire management, and threatened, sensitive, and endangered species will likely continue to dominate management and policy decisions. Policies that facilitate the management of rangeland ecosystems across administrative boundaries and that promote planning and management over longer time frames and larger spatial scales will be critical for implementing practices to respond to an increasingly variable climate. Developing reasonable response strategies and practices will require 1) accurate predictions of the changes that are likely to occur, especially at a management scale, 2) concepts and management approaches for dealing with the changes, and 3) policies and programs that will provide the necessary funds, mechanisms, and flexibility to implement large-scale adaptive management approaches.

Many of the necessary mechanisms for improving the quality of decisions and decreasing the barriers to effective land use planning are already in place, but need to be refined and revised for effective adaptive management. Conservation easements, migration corridors, watershed scale management, restoration of degraded ecosystems, and coordinated resource management are a few of the approaches that are used and understood by the public and agency staff and that have proven to be effective. Forecast changes in important climatic drivers and their influences on rangeland ecosystems clearly indicate the need for increased flexibility in both management plans and actions at regional, landscape, and local scales. Ranchers and land owners also require more options and greater flexibility to make economically sound decisions. Monitoring and systems to integrate monitoring results into management decisions are mandated already for most land management agencies. The linkages between monitoring and management need to be fully developed to track the changes occurring in response to both climate change and management actions and refine and revise management strategies over time. Successful adaptive management will require engaging stakeholders, integrating their concerns into land management objectives and, most importantly, explaining the changes that are likely to occur and the reality of responding to a changing climate.

\section{Additional Reading}

Bradley, B. A., R. A. Houghton, J. F. Mustard, and S. P. Hamburg. 2006. Invasive grass reduces aboveground carbon stocks in shrublands of the Western US. Global Change Biology 12:1815-1822.

Chambers, J. C., B. A. Roundy, R. R. Blank, S. E. Meyer, and A. Whittaker. 2007. What makes Great Basin sagebrush ecosystems invasible by Bromus tectorum? Ecological Monographs 77:117-145.

Deacon, J. E., A. E. Williams, C. Deacon Williams, and J. E. Williams. 2007. Fueling population growth in Las Vegas: how large-scale groundwater withdrawal could burn regional biodiversity. Bioscience 57:688-698.

D’Antonio, C. M., And P. M. Vitousek. 1992. Biological invasions by exotic grasses, the grass/fire cycle, and global change. Annual Review of Ecology and Systematics 23:63-87.

McKenzie, D., Z. Gedalof, D. L. Peterson, and P. Mote. 2004. Climate change, wildfire and conservation. Conservation Biology 18:890-902.

Miller, R. F., R. J. Tausch, D. E. McArthur, D. Johnson, and S. C. Sanderson. 2008. Development of post-settlement piñon-juniper woodlands in the intermountain west: a regional perspective. Research Paper RP-69. Fort Collins, CO, USA: USDA Forest Service, Rocky Mountain Research Station. $15 \mathrm{p}$.

Mote, P. W., A. F. Hamlet, M. P. Clark, and D. P. LettenMAIER. 2005. Declining mountain snowpack in western North America. Bulletin of the American Meteorological Society January:39-49.

Nielson, R. P., J. M. Lenihan, D. Bachelet, and R. J. Drapek. 2005. Climate change implications for sagebrush ecosytems. Transactions of the North American Wildlife and Natural Resources Conference. p. 145-159.

Smith, J. B., R. Richards, and B. Miller. 2006. Chapter 8. Potential consequences of climate variability and change for the 
western United States. U.S. Global Change Research Program. Available at: www.usgrcrp.gov/usgcrp/nacc/west.htm. Accessed 10 January 2008.

Wisdom, M. J., M. M. Rowland, and L. H. Suring. 2005. Habitat threats in the sagebrush ecosystem: methods of regional assessment and applications in the Great Basin. Lawrence, Kansas, USA: Alliance Communications Group. 301 p.
Authors are Research Ecologist, USDA Forest Service, Rocky Mountain Research Station, 920 Valley Road, Reno, NV 89509, USA, jchambers@fs.fed.us (Chambers); and Coordinator of the Great Basin Restoration Initiative, Bureau of Land Management, Idaho State Office, 1387 S Vinnell Way, Boise, ID 83709, USA (Pellant). 